\title{
Detection of doublecortin domain-containing 2 $(D C D C 2)$, a new candidate tumor suppressor gene of hepatocellular carcinoma, by triple combination array analysis
}

Yoshikuni Inokawa, Shuji Nomoto*, Mitsuhiro Hishida, Masamichi Hayashi, Mitsuro Kanda, Yoko Nishikawa, Shin Takeda, Hiroyuki Sugimoto, Tsutomu Fujii, Suguru Yamada and Yasuhiro Kodera

\begin{abstract}
Background: To detect genes correlated with hepatocellular carcinoma (HCC), we developed a triple combination array consisting of methylation array, gene expression array and single nucleotide polymorphism (SNP) array analysis.

Methods: A surgical specimen obtained from a 68-year-old female HCC patient was analyzed by triple combination array, which identified doublecortin domain-containing 2 (DCDC2) as a candidate tumor suppressor gene of HCC. Subsequently, samples from $48 \mathrm{HCC}$ patients were evaluated for their DCDC2 methylation and expression status using methylation specific PCR (MSP) and semi-quantitative reverse transcriptase (RT) PCR, respectively. Then, we investigated the relationship between clinicopathological factors and methylation status of DCDC2.

Results: $D C D C 2$ was revealed to be hypermethylated (methylation value 0.846 , range $0-1.0$ ) in cancer tissue, compared with adjacent normal tissue (0.212) by methylation array in the 68-year-old female patient. Expression array showed decreased expression of DCDC2 in cancerous tissue. SNP array showed that the copy number of chromosome 6p22.1, in which DCDC2 resides, was normal. MSP revealed hypermethylation of the promoter region of $D C D C 2$ in 41 of the tumor samples. DCDC2 expression was significantly decreased in the cases with methylation $(P=0.048)$. Furthermore, the methylated cases revealed worse prognosis for overall survival than unmethylated cases $(P=0.048)$.
\end{abstract}

Conclusions: The present study indicates that triple combination array is an effective method to detect novel genes related to HCC. We propose that DCDC2 is a tumor suppressor gene of HCC.

Keywords: DCDC2, Hepatocellular carcinoma, Methylation, Triple combination array

\section{Background}

Hepatocellular carcinoma (HCC) is currently the fifth most common malignancy worldwide [1], and its overall incidence is steadily rising. In spite of the therapeutic options for HCC such as hepatic resection [2], radiofrequency ablation [3], transcatheter arterial chemoembolization [4], and sorafenib [5], the prognosis of patients with advanced HCC remains poor [6,7]. Therefore, research to

\footnotetext{
* Correspondence: snomoto@med.nagoya-u.ac.jp

Gastroenterological Surgery, Nagoya University Graduate School of Medicine, Japan, 65 Tsurumai-cho, Showa-ku, Nagoya 466-8550, Japan
}

clarify the mechanisms of hepatocarcinogenesis is urgently required [8].

Gene expression microarray analysis has revealed many cancer-related genes in HCC [9]. This method enables the expression status of all genes to be investigated simultaneously [10]. Furthermore, single nucleotide polymorphism (SNP) arrays have made it possible to detect copy number changes as well as copy-neutral loss of heterozygosity (LOH) [11]. Recently we developed a double combination array analysis consisting of gene expression array and SNP array analysis, and reported a number of tumor suppressor genes in HCC [12-17]. In these

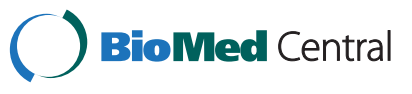


studies, we hypothesized that DNA methylation of the promoter region of these genes downregulated gene expression, causing $\mathrm{HCC}$ progression. In addition to this double combination array analysis, we obtained further data from the same specimens using methylation array analysis to make this association of DNA methylation more conclusive. We named it triple combination array analysis; this method seems to be an efficient procedure for the detection of tumor suppressor genes of HCC [18].

Doublecortin domain-containing $2(D C D C 2)$ is a candidate tumor suppressor gene detected by this triple combination array analysis. This gene encodes a member of the doublecortin family [19], and contains two doublecortin domains. The doublecortin domain has been demonstrated to bind tubulin and enhance microtubule polymerization $[19,20]$, and mutations in this gene have been associated with dyslexia [21-24]. However, there are only a few reports of the relationship between $D C D C 2$ and cancer [25]. In addition, no previous study has researched the role of $D C D C 2$ in HCC. Although it had been considered that $D C D C 2$ gene had an impotrtant role in neuroendocrine systems, the expression of the gene was reported in GeneCards relatively strongest in liver in whole human organs including brain. Therefore, we selected this gene for this study, because we predicted the gene might have some role in liver.

\section{Methods}

\section{Sample collection and DNA preparation}

Nine HCC cell lines (HepG2, Hep3B, HLE, HLF, HuH1, $\mathrm{HuH} 2, \mathrm{HuH} 7, \mathrm{PLC} / \mathrm{PRF}-5$ and SK-Hep1) were obtained from the American Type Culture Collection (Manassas, VA, USA). The cell lines were cultured in RPMI-1640 supplemented with $10 \%$ fetal bovine serum, and incubated in $5 \% \mathrm{CO}_{2}$ at $37^{\circ} \mathrm{C}$.

A 68-year-old woman with chronic hepatitis $\mathrm{C}$ was diagnosed with $\mathrm{HCC}$ in the right lobe and underwent liver resection. Specimens of her tumor and adjacent nontumorous tissues were excised, and total RNA and DNA were extracted. Total RNA was sent to the manufacturer of Affymetrix to prepare it for expression array analysis. Genomic DNA was used for a SNP-Chip array, and bisulfite-converted DNA was used for the Ilumina Infinium HumanMethylation 27 BeadChip (Illumina, San Diego, CA, USA). The tumor was pathologically confirmed as HCC. RNA and DNA of tumor samples were extracted from an area consisting of $>80 \%$ cancerous cells.

HCC tissue (HTs) and normal tissue (NTs) samples were obtained from 48 patients (43 males, five females) who underwent liver resection at Nagoya University Hospital, Nagoya, Japan between 1994 and 2001. The patients were aged from 39 to 77 years (mean \pm SD, $62.4 \pm$ 7.9 years). Thirty-eight patients had hepatitis $C$ and seven had hepatitis B. The median duration of follow-up was 80.7 months (range 15.2-213.1 months). All tissues were reviewed pathologically to confirm the diagnosis of HCC. Written informed consent, as required by the institutional review board, was obtained from all patients. The tissue samples were immediately frozen in liquid nitrogen and stored at $-80^{\circ} \mathrm{C}$ until required. Genomic DNA was obtained from the tissue samples by proteinase $\mathrm{K}$ digestion, followed by phenol/chloroform extraction.

\section{RNA isolation, microarray and gene chip affymetrix procedures}

The expression array and SNP array were performed, as previously described [12-17], using total RNA and DNA extracted from the 68-year-old woman's tissue samples.

\section{Methylation array platform}

The Illumina Infinium HumanMethylation27 BeadChip protocol requires $500 \mathrm{ng}$ to $1 \mu \mathrm{g}$ of bisulfite-converted DNA [26]. Of the approximately 28 million CpG sites found throughout the haploid human genome, Illumina initially designed Infinium methylation probes for 27,578 CpG sites located in promoter regions (up to $1 \mathrm{~kb}$ upstream or $500 \mathrm{bp}$ downstream of the transcription start sites). Of these, 27,324 CpG sites relate to 14,475 consensus coding sequences, including around 1000 cancer-associated genes, and 254 CpG sites relate to approximately 100 micro-RNA genes. The probes were preferentially selected to occur within $\mathrm{CpG}$ islands using the $\mathrm{NCBI}$ "relaxed" definition of a CpG island: CpG islands identified bioinformatically with a CpG content of $>50 \%$ and an observed/expected ratio of $>0.6$ [27].

Bisulfite-converted DNA is then whole-genome amplified, enzymatically fragmented, and hybridized to the array. During hybridization, the bisulfite-converted DNA anneals to methylation-specific probes on the chip. Each CpG locus is represented by two bead types, one of which is specific to the methylated state and the other is specific to the unmethylated state, which is directly related to the underlying sequence change catalyzed during bisulfite conversion. Therefore, for each $\mathrm{CpG}$ site, a possible $\mathrm{C} / \mathrm{T}$ variant can be assayed through the singlebase extension step, which is possible because of the ability to hybridize to either the "protected" methylated cytosine or the converted (unmethylated) thymine.

After hybridization, a single-base extension step is carried out using a multi-layer staining process, as described below. The BeadChip is then scanned on the Illumina iScan and the resulting "idat" files are analyzed 
using BeadStudio software. The output of the BeadStudio analysis is a $\beta$-value for each CpG site. This is a continuous value between 0 and 1 where $0=0 \%$ methylation and $1=100 \%$ methylation at a given CpG site. Therefore, this assay enables quantitative analysis of methylation at individual CpG sites.

\section{Reverse transcription-polymerase chain reaction (RT-PCR)} DCDC2 mRNA expression was analyzed by semiquantitative RT-PCR and real-time RT-PCR. Total RNA $(10 \mu \mathrm{g})$ isolated from nine HCC cell lines, primary HTs and NTs were used to generate cDNAs. The resulting cDNAs were then amplified by PCR primers for $D C D C 2$ (sense, 5' - GCT TCA GGA GCC GTG CAC TA -3' in exon 4); antisense $5^{\prime}$ - CCC CGC TCC TCA GAG TGA TT -3 ' in exon 5), which amplified a 146-bp product. Initial denaturation at $94^{\circ} \mathrm{C}$ for $5 \mathrm{~min}$ was followed by amplification consisting of 35 cycles of $94^{\circ} \mathrm{C}$ for $10 \mathrm{~s}, 60^{\circ} \mathrm{C}$ for $8 \mathrm{~s}$, and $72^{\circ} \mathrm{C}$ for $6 \mathrm{~s}$. RT-PCR of beta-actin was performed to confirm equal amounts of cDNA was used as templates. Each PCR product was loaded directly onto $3 \%$ agarose gels, stained with ethidium bromide, and visualized under UV illumination.

\section{Real-time quantitative RT-PCR analysis}

PCR was performed with the SYBR Green PCR Core Reagents kit (Perkin-Elmer Applied Biosystems, Foster City, CA, USA) under the following conditions: 1 cycle at $95^{\circ} \mathrm{C}$ for $10 \mathrm{~s}$, followed by 40 cycles at $95^{\circ} \mathrm{C}$ for $5 \mathrm{~s}$ and at $60^{\circ} \mathrm{C}$ for $30 \mathrm{~s}$. SYBR Green emission was detected in real-time with an ABI prism 7000 Sequence Detector (Perkin-Elmer Applied Biosystems). The primers used in PCR were the same as those described above for RTPCR. For standardization, the expression of GAPDH was quantified in each sample. Quantitative RT-PCR was performed at least three times, including negative controls without template. The expression of $D C D C 2$ was normalized for that of $G A P D H$ in each sample.

\section{Methylation-specific PCR (MSP)}

DNA from HCC cell lines, HTs and NTs were subjected to bisulfite treatment. Briefly, $2 \mu \mathrm{g}$ of DNA was denatured by $\mathrm{NaOH}$ and modified by sodium bisulfite. DNA samples were then purified using the Wizard purification resin (Promega Corp., Madison, WI, USA), treated with $\mathrm{NaOH}$, precipitated with ethanol, and resuspended in water. Primer pairs were used to detect methylation (sense, 5' - AGG TCG TTG GGA TAG CGG AG -3'; antisense, 5' - TCA TCT TCC CCG CTA ACC GC -3'; 73-bp product) and non-methylation (sense, 5' - GGG TGT GGT GAG GTT GTT GG -3'; antisense, 5' - CTT CCC CAC TAA CCA CCA CC -3'; 79-bp product) of the $D C D C 2$ promoter region near exon 1 . The MSP and unmethylated-specific PCR (UNMSP) amplification consisted of denaturation at $94^{\circ} \mathrm{C}$ for 5 min followed by 35 cycles at $94^{\circ} \mathrm{C}$ for $8 \mathrm{~s}, 60^{\circ} \mathrm{C}$ for $5 \mathrm{~s}$, and $72^{\circ} \mathrm{C}$ for $3 \mathrm{~s}$. The PCR products were loaded directly onto $3 \%$ agarose gels, stained with ethidium bromide, and visualized under UV illumination.

\section{Sequence analysis}

Bisulfite-treated genomic DNA obtained from HCC cell lines was sequenced and PCR was performed in all cases. We performed semi-nested PCR to gain adequate products for TA cloning. PCR amplification consisted of denaturation at $94^{\circ} \mathrm{C}$ for 3 min followed by 35 cycles of $94^{\circ} \mathrm{C}$ for $10 \mathrm{~s}, 52^{\circ} \mathrm{C}$ for $10 \mathrm{~s}$ and $72^{\circ} \mathrm{C}$ for $20 \mathrm{~s}$ with primer pairs (sense 5' - TTT AGT GTT TTT TTT GGG TG -3'; antisense, 5' - CTA AAC ACC TTC TTC TCA TG -3'; 312-bp product). The products were used as templates of subsequent PCRs with primer pairs consisting of the same sense, and different antisense (antisense, 5' - AAC AAA TAA CTA AAC CTA AC -3'; 219-bp product). The PCR products were subcloned into a TA cloning vector (Invitrogen, Carlsbad, CA, USA). Six cloning samples were picked out from two HCC cell lines (HuH2 and SK-Hep1). Each DNA clone was mixed with $3 \mu \mathrm{l}$ of the specific primer (M13) and $4 \mu \mathrm{l}$ of Cycle Sequence Mix (ABI PRISM Terminator v1. 1 Cycle Sequencing Kit; Applied Biosystems, Foster City, CA, USA). Samples were then subjected to the following cycling conditions: $95^{\circ} \mathrm{C}$ for $30 \mathrm{~s}$ followed by 25 cycles of $96^{\circ} \mathrm{C}$ for $10 \mathrm{~s}, 50^{\circ} \mathrm{C}$ for $5 \mathrm{~s}$, and $60^{\circ} \mathrm{C}$ for $4 \mathrm{~min}$, and then purified by ethanol precipitation. Sequence analysis was carried out using an Applied Biosystems ABI310, and sequence electropherograms were generated using ABI Sequence Analysis software version 3.0.

\section{5-Aza-2'-deoxycytidine (5-aza-dC) treatment}

To confirm that promoter hypermethylation was responsible for silencing of gene expression, the nine $\mathrm{HCC}$ cell lines were treated with $1 \mu \mathrm{M} 5$-aza-dC (Sigma-Aldrich, St. Louis, MO, USA) to inhibit DNA methylation. Cells $\left(1.5 \times 10^{6}\right)$ were cultured for 6 days with medium changes on days 1,3 , and 5 . On day 6 , the cells were harvested, RNA was extracted, and RT-PCR was performed as described above.

\section{Western blotting analysis}

Cultured cells were washed twice with phosphatebuffered saline and lysed by lithium dodecyl sulfate (LDS) buffer (Invitrogen). Protein lysates were resolved on $10 \%$ SDS polyacrylamide gel, electrotransferred to polyvinylidene fluoride membranes using iBlot Gel Transfer Device (Invitrogen) and blocked in 5\% nonfat 
dry milk. Membranes were immunoblotted overnight at $4^{\circ} \mathrm{C}$ with a rabbit anti-DCDC2 antibody (ab106283; Abcam plc, Cambridge, UK) followed by peroxidaseconjugated secondary antibodies. As a control, a mouse monoclonal anti-beta-actin antibody (Abcam plc,) was used. Signals were detected by enhanced chemiluminescence (Lumivision PRO HSII, Aisin Seiki Co., LTD, Kariya, Japan).

\section{Immunohistochemistry}

We investigated DCDC2 protein expression by immunohistochemistry in the same samples analyzed by the arrays and in 38 HCCs whose samples were available in a well-preserved condition. Cut sections were prepared from formalin-fixed and paraffin-embedded tissues for DCDC2 staining. Samples were treated with $3 \% \mathrm{H}_{2} \mathrm{O}_{2}$ to inhibit endogenous peroxidase, and then subjected to antigen retrieval using $10 \mathrm{mM}$ citrate buffer five times at $95^{\circ} \mathrm{C}$ for $10 \mathrm{~min}$. Sections were incubated with Histofine SAB-PO(R) (Nichirei, Tokyo, Japan) for $10 \mathrm{~min}$, to limit non-specific reactivity, and then incubated with DCDC2 antibody produced in rabbit (ab106283; Abcam plc) diluted 1:2000 in ChemMatet antibody diluent (Dako) for $12 \mathrm{~h}$. All stains were developed for $15 \mathrm{~min}$ using liquid diaminobenzidine (DAB) as the substrate (Nichirei). We determined staining properties setting vessels as integral control, and made a comparison of DCDC2 expression between HCC tissues and corresponding non-cancerous tissues. To avoid being subjective, specimens were randomized and coded before analysis, which was conducted by two independent observers, who evaluated all specimens at least twice within a given interval to minimize intra-observer variation.

\section{Statistical analysis}

Continuous variables are expressed as medians (range) and comparisons were made using the Mann Whitney U test. Categorical variables were compared using $X^{2}$ tests or Fisher's exact tests, where appropriate. Overall survival rates were analyzed by Kaplan-Meier and log-rank tests. All statistical analyses were performed using JMP software version 9.0.2 (SAS International Inc., Cary, NC, USA). The level of statistical significance was set at $P<0.05$.

\section{Results}

\section{Results of expression, SNP, and methylation-arrays}

To identify novel tumor-related genes in HCC, we first searched for genes with decreased expression in HCC samples compared with corresponding normal tissue. According to the expression array results, $D C D C 2$ was strongly downregulated in HCC tissue. The decreased values (log 2 ratio) were -2.2 in a point of the expression array chip (Table 1).
Table 1 Expression array analysis of the 68-year-old female's surgical HCC sample

\begin{tabular}{llllll}
\hline $\begin{array}{l}\text { Probe set } \\
\text { ID }\end{array}$ & $\begin{array}{l}\text { Gene } \\
\text { symbol }\end{array}$ & $\begin{array}{l}\text { Log2 } \\
\text { ratio }\end{array}$ & Sample & Signal & Detection \\
\hline 222925_at & DCDC2 & $\mathbf{- 2 . 2}$ & Normal & 148.3 & $\mathrm{P}$ \\
& & & Tumor & 36.9 & $\mathrm{P}$ \\
\hline
\end{tabular}

HCC hepatocellular carcinoma, DCDC2 doublecortin domain-containing 2 .

We confirmed reduced expression of DCDC2 mRNA in tumor tissue by semi-quantitative RT-PCR in the case whose samples were used for the array analysis (Figure 1a).

Next, we checked the results of the SNP array. We observed deletions in 3q, 8p, 11q, 12p, 12q, 16p, 17p, $19 \mathrm{p}$, and $\mathrm{X}$ chromosomes, and chromosomal gain in $1 \mathrm{q}$, $3 \mathrm{q}, 11 \mathrm{q}, 12 \mathrm{p}$, and 12q. The copy number of chromosome 6, which contains $D C D C 2$, did not show any deletions and amplifications (Figure 1b). Also, we looked for detailed data of the SNP array at the $D C D C 2$ gene locus at 6 22.1, and found 29 SNPs. Twelve of these 29 SNPs showed a heterozygous $\mathrm{AB}$ allele in both the noncancerous and cancerous samples (Table 2). These results suggest that the $D C D C 2$ gene locus retained biallelically.

We subsequently checked the results of the methylation array: the continuous $\beta$-values were 0.846 for tumor tissue versus 0.212 for normal tissue, indicating high methylation in HCC sample (Table 3). Using MSP, we confirmed hypermethylation in this gene in the tumor tissue obtained from the 68-year-old woman whose DNA was used for the methylation array (Figure 1c). These results implied that $D C D C 2$ expression decreased without $\mathrm{LOH}$, possibly because of hypermethylation at the promoter region.

\section{Effects of inhibiting methylation on DCDC2 expression in nine HCC cell lines}

To confirm that promoter hypermethylation led to silencing of $D C D C 2$ expression, we checked the mRNA expression of the gene before and after 5-aza-dC treatment of nine $\mathrm{HCC}$ cell lines. The expression of $D C D C 2$ in five of these lines, HLE, HLF, HuH1, HuH2 and PLC/PRF/5, was clearly reactivated by 5 -aza- $\mathrm{dC}$ treatment, as shown by semi-quantitative RT-PCR (Figure 2a).

MSP and UNMSP of nine HCC cell lines and one HCC case Then, we designed primers for methylation-specific (MSP) and non-methylation-specific PCR (UNMSP) and checked the methylation status of nine HCC cell lines. For MSP, we obtained bands of appropriate size in lanes containing HLE, HLF, HuH1, HuH2, HuH7, PLC/PRF/5 samples, while in UNMSP, appropriate bands were 
a

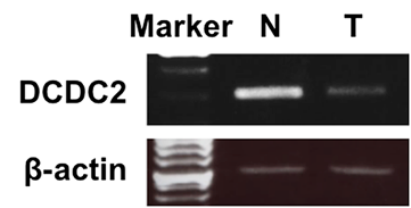

b

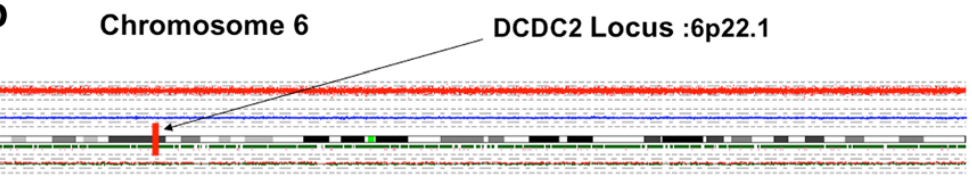

C

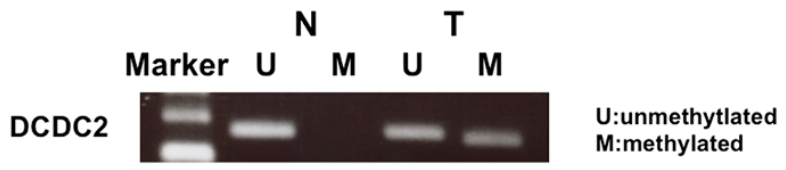

Figure 1 Results of experiments from a specimen from a 68-year-old woman. (a) Semi-quantitative RT-PCR showed downregulation of DCDC2 in the tumor sample compared with corresponding normal tissue. (b) Copy number analysis of chromosome 6 by SNP array in the HCC sample did not show any deletion or amplification on 6p22.1, the DCDC2 locus. (c) MSP showed promoter hypermethylation in the tumor sample alone.

identified in lanes for all cell lines except $\mathrm{HuH} 2$ (Figure 2b). We subsequently identified complete methylation in $\mathrm{HuH} 2$, partial methylation in HLE, HLF, HuH1, HuH7 and PLC/PRF/5, and no methylation in HepG2, Hep3B and SK-Hep1.

\section{Sequence analysis}

To confirm that MSP amplification was correctly performed, we executed sequence analysis of the $D C D C 2$ promoter region in $\mathrm{HuH} 2$ and SK-Hep1 cells. Almost all CpG dinucleotides in $\mathrm{HuH} 2$ were methylated, while those of SK-Hep1 were unmethylated (Figure 3). These results verified the accuracy of MSP and UNMSP.
MSP and UNMSP of normal and tumor tissues from 48 HCC patients

Overall, 41 of the $48(85.4 \%)$ tumor samples displayed $D C D C 2$ promoter hypermethylation, whereas only 9 of 48 samples showed hypermethylation in the normal samples (Figure 4a). Thus, hypermethylation of $D C D C 2$ was significantly more frequent in tumor tissues $(P<0.001)$. Four representative cases of MSP and UN-MSP status are shown in Figure 4b.

Real-time quantitative RT-PCR analysis of $48 \mathrm{HCC}$ patients We also examined the expression levels of $D C D C 2$ mRNA by real-time RT-PCR in the 48 analyzed cases,

Table 2 Results of SNP signal at the DCDC2 gene locus

\begin{tabular}{|c|c|c|c|c|c|c|}
\hline Probe set ID & Chromosome & Physical position & Normal call & Confidence & Tumor call & Confidence \\
\hline SNP_A-2175183 & 6 & 24175005 & $A B$ & 0.007813 & $A B$ & 0.023438 \\
\hline SNP_A-1934540 & 6 & 24175527 & $A B$ & 0.007813 & $A B$ & 0.007813 \\
\hline SNP_A-2079666 & 6 & 24202016 & $A B$ & 0.015625 & $A B$ & 0.015625 \\
\hline SNP_A-1920269 & 6 & 24202874 & $A B$ & 0.0625 & $A B$ & 0.132813 \\
\hline SNP_A-2242966 & 6 & 24227520 & $A B$ & 0.007813 & $A B$ & 0.007813 \\
\hline SNP_A-1825242 & 6 & 24238542 & $A B$ & 0.023438 & $A B$ & 0.0625 \\
\hline SNP_A-4233820 & 6 & 24241681 & $A B$ & 0.125 & $A B$ & 0.0625 \\
\hline SNP_A-2042383 & 6 & 24317865 & $A B$ & 0.023438 & $A B$ & 0.007813 \\
\hline SNP_A-2136345 & 6 & 24330431 & $A B$ & 0.007813 & $A B$ & 0.007813 \\
\hline SNP_A-4215128 & 6 & 24330575 & $A B$ & 0.015625 & $A B$ & 0.132813 \\
\hline SNP_A-4242164 & 6 & 24353402 & $A B$ & 0.047363 & $A B$ & 0.02832 \\
\hline SNP_A-1870108 & 6 & 24356599 & $A B$ & 0.0625 & $A B$ & 0.039063 \\
\hline
\end{tabular}

SNP single nucleotide polymorphism, DCDC2 doublecortin domain-containing 2 . 
Table 3 Methylation array analysis of the 68-year-old female's surgical HCC sample

\begin{tabular}{|c|c|c|c|c|c|c|c|c|}
\hline \multirow{2}{*}{ Probe ID } & \multirow{2}{*}{$\begin{array}{l}\text { Gene } \\
\text { symbol }\end{array}$} & \multirow[t]{2}{*}{ Sample } & \multirow{2}{*}{$\begin{array}{c}\text { Methylation } \\
\text { value(0-1) }\end{array}$} & \multicolumn{3}{|c|}{ Status } & \multirow{2}{*}{ Confidence } & \multirow{2}{*}{$\begin{array}{l}\text { Chromosomal } \\
\text { location }\end{array}$} \\
\hline & & & & Total & Unmethylated & Methylated & & \\
\hline \multirow{2}{*}{ cg 16306115} & \multirow{2}{*}{ DCDC2 } & Normal & 0.212 & 7096 & 5569 & 1527 & $3.68 \mathrm{E}-38$ & \multirow{2}{*}{ Chr6p22.1 } \\
\hline & & Tumor & 0.846 & 9684 & 1399 & 8285 & $3.68 \mathrm{E}-38$ & \\
\hline
\end{tabular}

HCC hepatocellular carcinoma, DCDC2 doublecortin domain-containing 2.

calculated as the value of $D C D C 2$ mRNA expression divided by that of GAPDH for each sample. The $D C D C 2$ expression index was calculated as the value of the tumor tissue expression level divided by that of the expression level of the adjacent normal tissue. With regard to the correlation between methylation status and expression index, hypermethylated cancerous tissues had significantly lower $D C D C 2$ expression index than other tissue examined ( $P=0.048$; Figure 5a). However, methylation in normal tissue did not show significant difference in expression index $(P=0.153$; Figure $5 b)$.

\section{Western blotting}

Evaluation by western blotting confirmed DCDC2 protein expression after 5-aza-dC treatment in $\mathrm{HuH} 2$ and SK-Hep1 cells was consistent with that of RT-PCR. The expression of $D C D C 2$ in the cells was also reactivated by the treatment in $\mathrm{HuH} 2$ cells that were completely methylated (Figure 6).

\section{Immunohistochemical staining of $D C D C 2$}

In the $24(63.1 \%)$ of 38 cases that underwent immunohistochemical staining, the cancerous components showed reduced DCDC2 protein expression compared with adjacent non-cancerous tissue. In 18 of 31 methylated cases, and in six of seven unmethylated cases, the cancerous tissues showed downregulated DCDC2, and there was no significant relationship between methylation status and $\mathrm{DCDC} 2$ protein expression, suggesting that there could be other silencing mechanisms involved in HCC (Figure 7).

Correlation between promoter hypermethylation status of $D C D C 2$ gene and clinicopathological characteristics in 48 HCC patients

We analyzed the correlation between the hypermethylation status of $D C D C 2$ and clinicopathological features of the $48 \mathrm{HCC}$ patients. Whereas no notable association between the methylation status and clinicopathological variables was detected (data not shown), the methylated cases showed poorer prognosis of overall survival than the unmethylated cases $(P=0.048$; Figure 8).

\section{Discussion}

Recent studies have investigated the relationship between carcinogenesis and DNA methylation in different cancer types [28-30]. Methylation in a number of genes in HCC has also been investigated worldwide [31-34]. However, it is unknown whether methylated genes in HCCs are associated with gene expression, or prognosis of the patients.

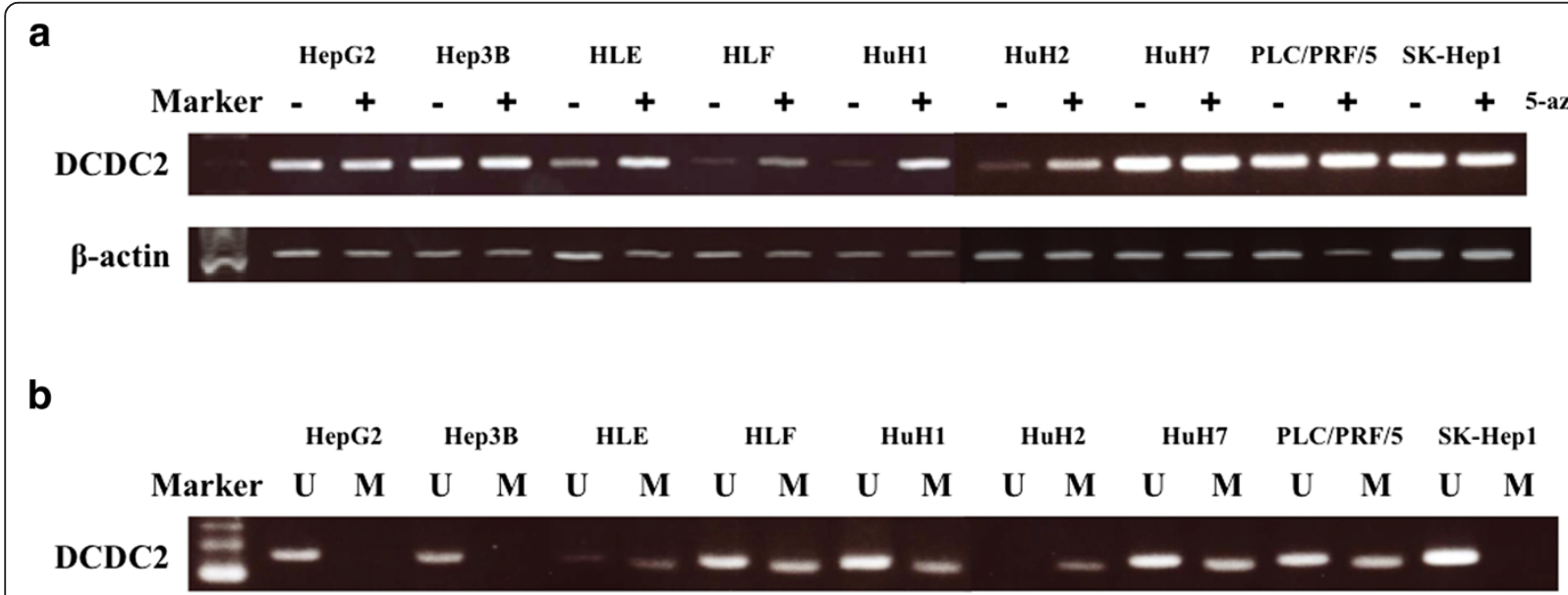

Figure 2 Results of Semi-quantitative RT-PCR and MSP in nine HCC cell lines. (a) Semi-quantitative RT-PCR showed reactivation of DCDC2 expression in five (HLE, HLF, HuH1, HuH2 and PLC/PRF/5) of nine HCC cell lines. (b) MSP showed complete methylation in HuH2, partial methylation in HLE, HLF, HuH1, HuH7 and PLC/PRF/5, and no methylation in HepG2, Hep3B and SK-Hep1. 


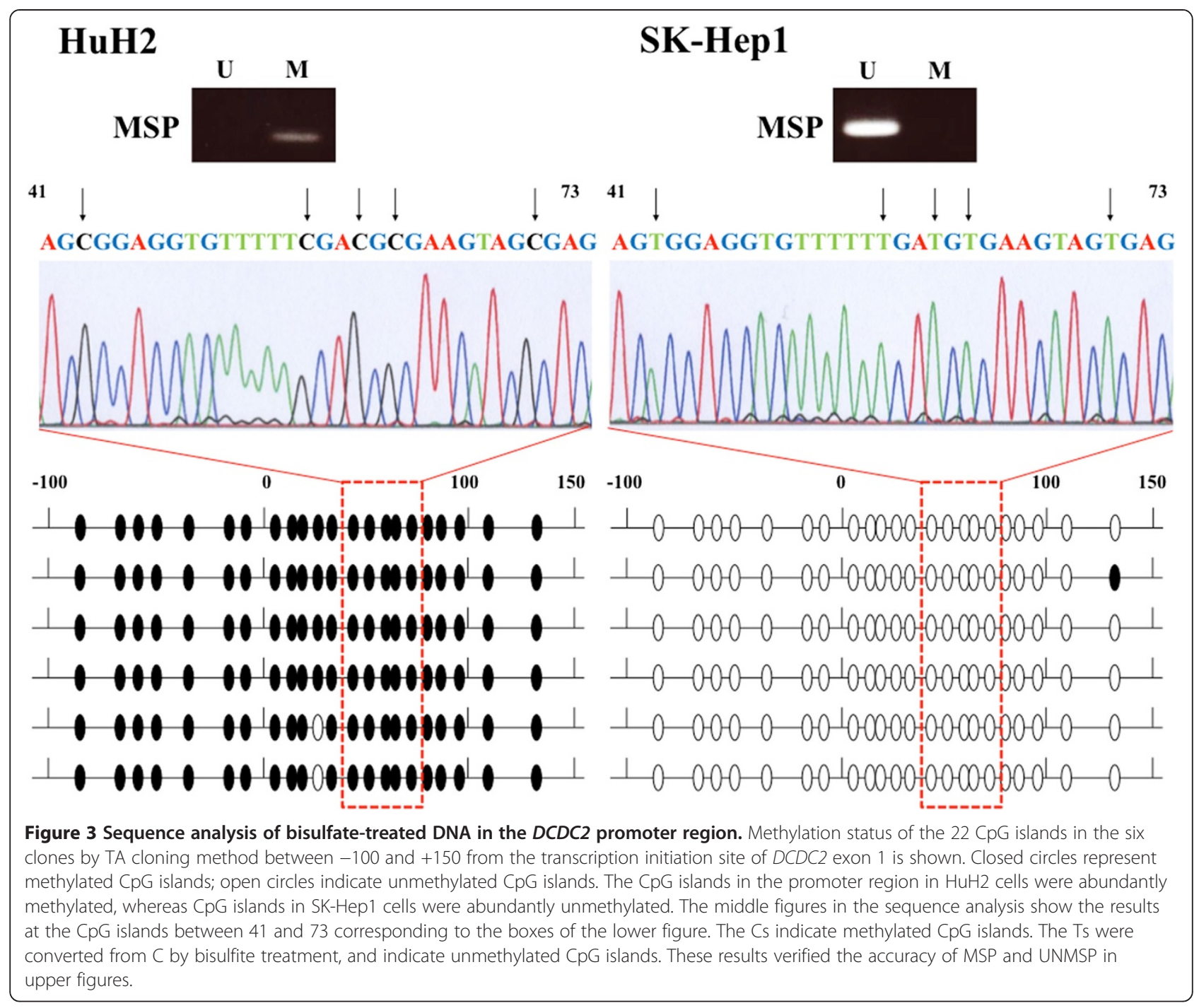

To detect new cancer-related genes that enable prediction of the prognosis of patients who undergo hepatectomy for HCC, we developed a double combination array analysis consisting of expression array and SNP array analysis, and have reported several genes associated with hepatocarcinogenesis [12-17]. Our experiment proves that these genes were hypermethylated in HCC tumor tissues, resulting in decreased expression and poorer prognosis, and we realized the double combination array analysis was an efficient procedure to identify new cancer-related genes via an epigenetic mechanism. However, this procedure required validation in $\mathrm{HCC}$ specimens on the basis that the downregulation of these genes occurred by methylation of promoter regions. To ensure the involvement of gene methylation, we developed a triple combination array analysis that consists of expression array, SNP array, and methylation array analysis, and reported a new tumor suppressor gene using this procedure [18].
In the current study, we identified $D C D C 2$ as a candidate tumor suppressor gene in HCC using triple combination array analysis. The promoter region of this gene was hypermethylated in many cancer tissues but only in a few normal tissues. The expression of $D C D C 2$ in tumor tissues was decreased in methylated cases $(P=0.048)$. The overall survival of the patients with $D C D C 2$ methylation was significantly worse than those without methylation $(P=0.048)$.

$D C D C 2$ has been reported as a gene related with dyslexia [21-24]. DCDC2 protein is considered to have important roles in neural migration and construction of microtubules [19-21]. Massinen et al. showed downregulation of DCDC2 expression enhanced Wnt signaling, which is important in neuronal development [35]. Moreover, it is known that aberrant activation of the Wnt pathway is associated with human malignancies, including HCC [36,37]. Therefore, it could be hypothesized 


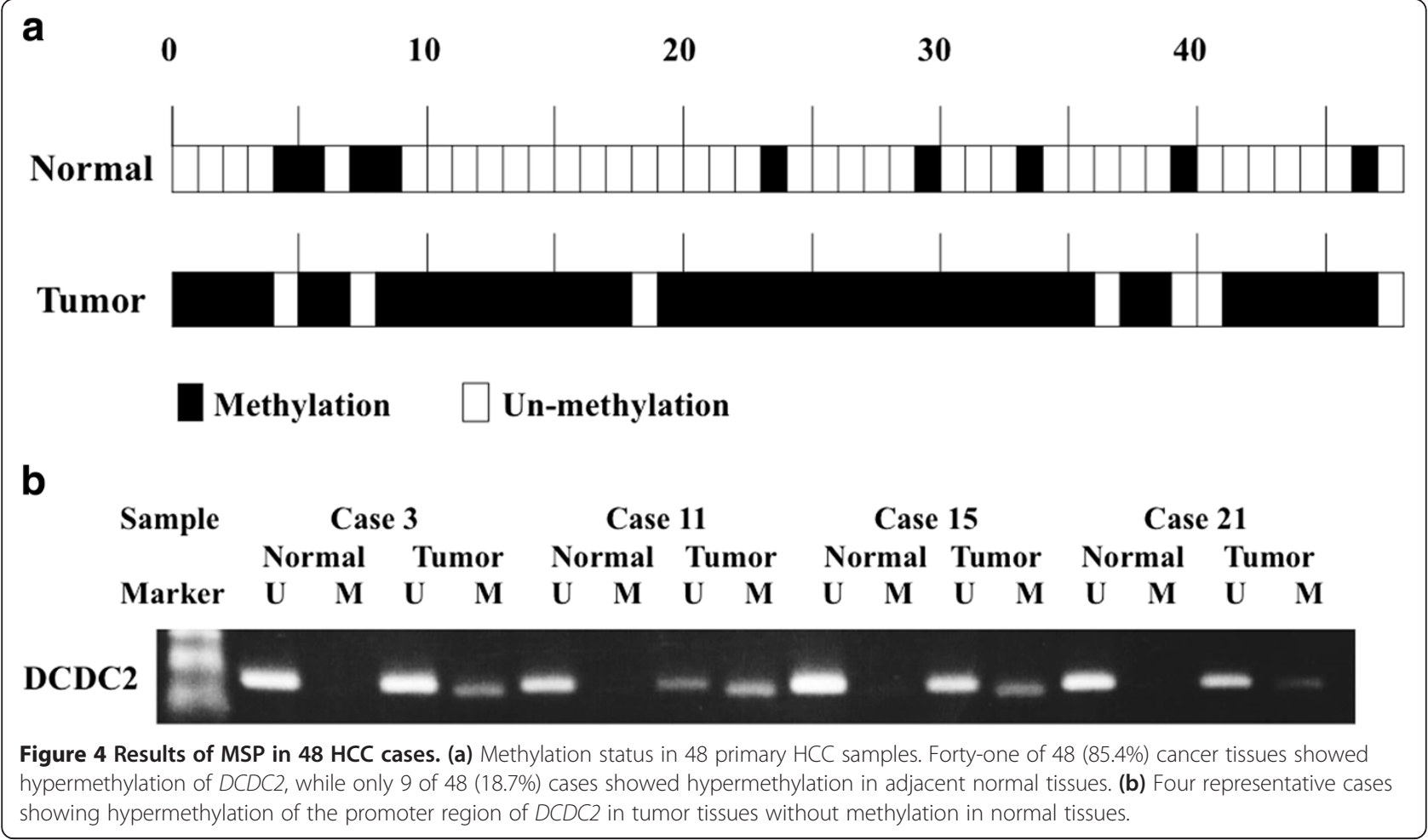

that methylation of $D C D C 2$ downregulates the expression of its protein product to cause activation of the Wnt pathway and worsen the prognosis of HCC patients. To support this hypothesis, various studies investigated secreted frizzled-related protein 1 (SFRP1) in HCC [38-41], and Kaur $\mathrm{P}$ et al. indicated SFRP1 expression was down-

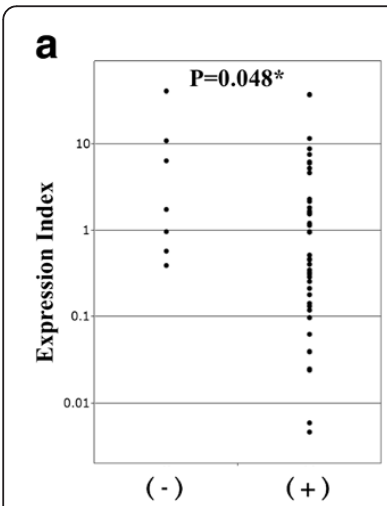

Methylation of tumor tissue

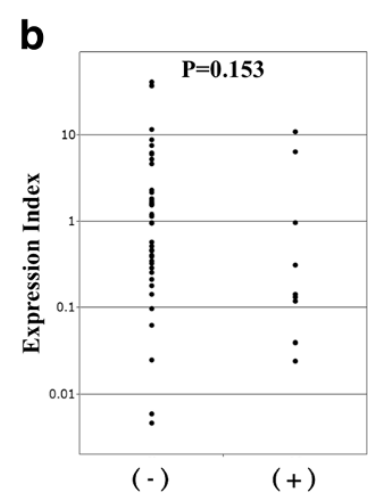

Methylation of normal tissue
Figure 5 Results of quantitative RT-PCR in $\mathbf{4 8}$ HCC cases.

(a) Expression levels of DCDC2 mRNA examined by RT-PCR in 48 cases. The expression index [(DCDC2-tumor) $\times($ GAPDH-normal) $/(D C D C 2$ normal) $\times($ GAPDH-tumor)] was calculated for all 48 cases.

Expression index in methylated cases were significantly lower than unmethylated cases $(P=0.048)$. (b) Methylation in normal tissue did not show significant difference in expression index $(P=0.153)$. regulated by methylation resulting in activation of the Wnt pathway and contributing to increased HCC cell growth and proliferation [41]. Therefore, $D C D C 2$ might play a role in $\mathrm{HCC}$ in similar way to SFRP1.

One of the limitations of this method is that we can obtain array information from only one pair of resected specimens at a time. However, we identified $D C D C 2$ by triple combination array analysis. Thus, we investigated this gene in 48 resected $\mathrm{HCC}$ specimens and proved the impact of methylation in cancer tissues. The relevance of $D C D C 2$ in the tumorigenesis of HCC could therefore be considered as universal. Another limitation is that the

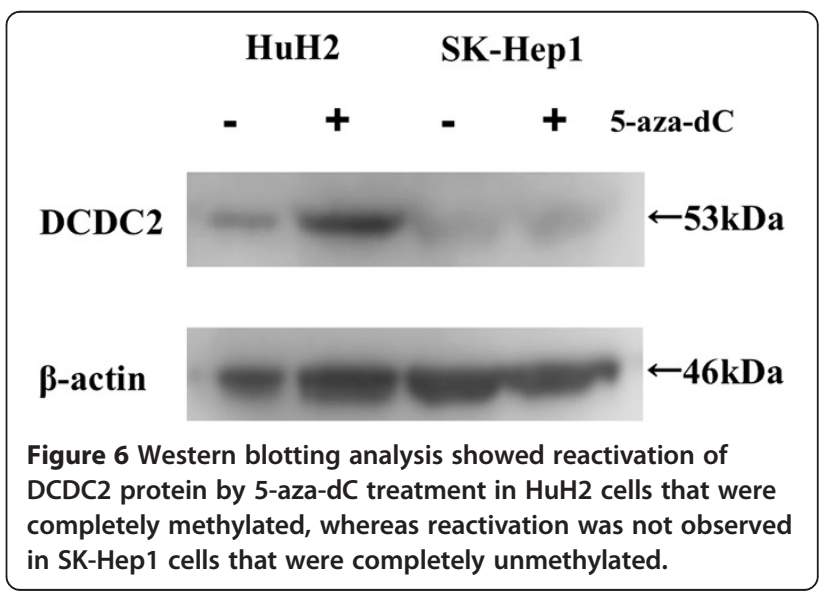




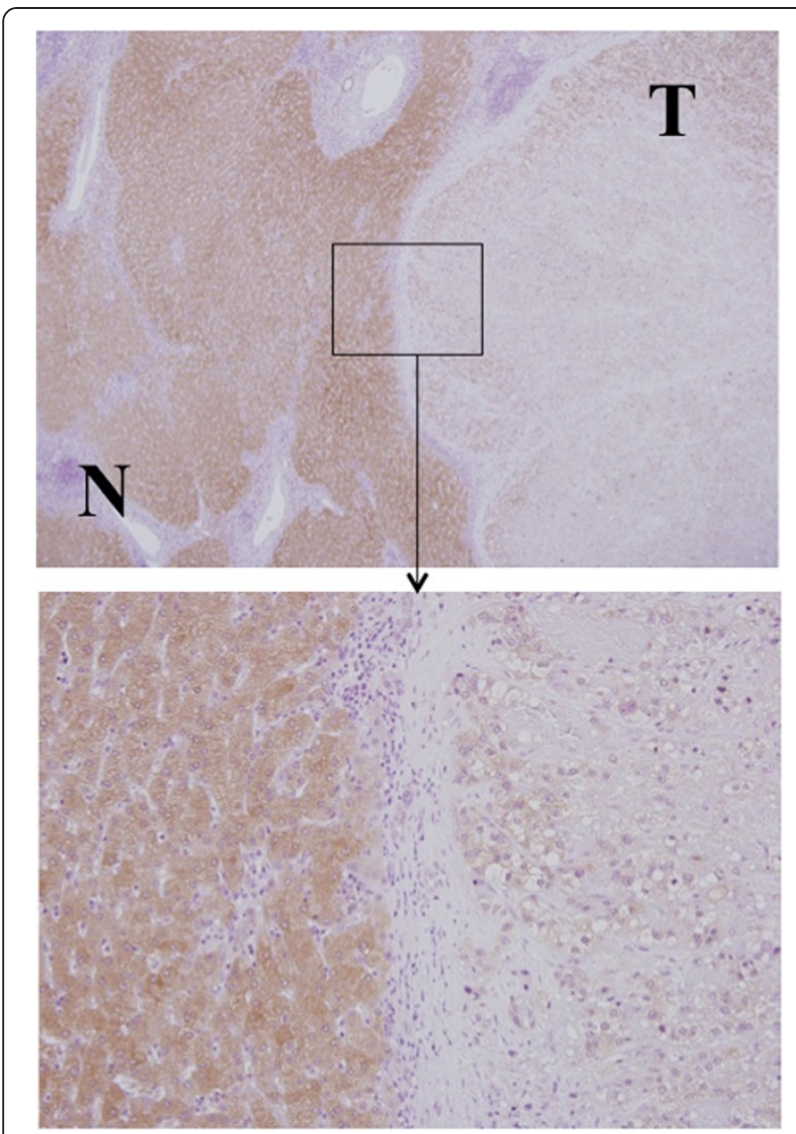

Figure 7 Representative finding of immunohistochemical staining of DCDC2 in a resected sample. Strong staining was observed in the cytoplasm of non-cancerous cells, whereas weak staining was present in tumor cells (upper picture: magnification 40x, lower picture: magnification 200x).

results of immunohistochemical staining and DNA methylation status did not show significant association. We consider that the methylation is not the only mechanism that regulates the protein expression. Other mechanisms such as histone deacetylation or post-transcriptional regulation by microRNAs might play a role in regulation of DCDC2 protein expression $[42,43]$. However, our results showed the contribution of methylation in mRNA expression and prognosis after surgery.

Taken together, the methylation of $D C D C 2$ could be a prognostic marker after surgical resection of HCC. Furthermore, decitabine has become a therapeutic agent for patients with myelodysplastic syndrome (MDS) by DNA hypomethylation [44]. It is considered that p15 and other methylated genes may be therapeutic targets of the DNA methylation-inhibitory activity of decitabine in MDS [45]. In the future, it might be applied in the clinical setting for HCC patients who have methylated $D C D C 2$ in their tumor tissue.

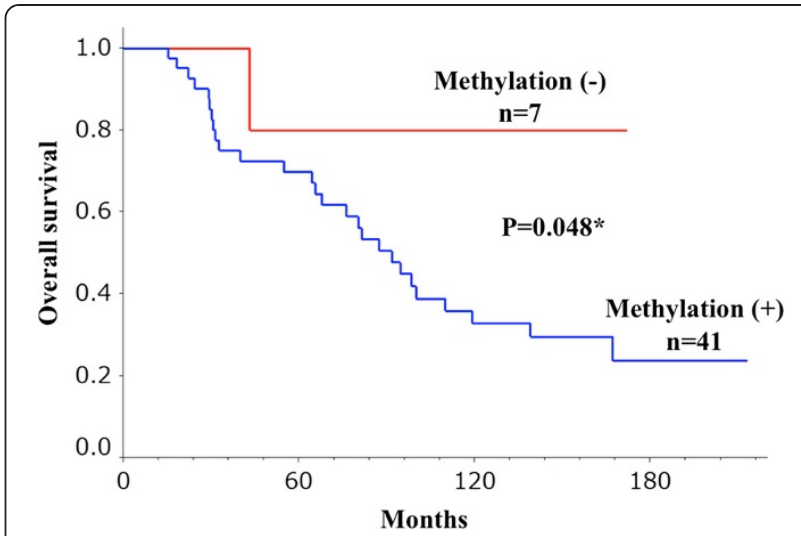

Figure $\mathbf{8}$ Overall survival stratified by methylation status of $D C D C 2$. Methylated cases of tumor tissues were significantly correlated with a worse prognosis compared with that of unmethylated cases $(P=0.048)$.

\section{Conclusions}

In conclusion, our triple combination array analysis detected $D C D C 2$ as a candidate tumor suppressor gene in HCC. Additional investigations of the function of this gene in carcinogenesis are required to confirm this gene as a bona fide tumor suppressor. According to our clinical data from $48 \mathrm{HCC}$ specimens, the extent of promoter hypermethylation for this gene correlated with overall survival. Further studies will be required to evaluate the effect of $D C D C 2$ re-expression in HCC cells by a methylation inhibitor. If re-expression with such an agent can inhibit tumor growth, this may represent a key line of therapy for advanced HCC tumors.

\section{Abbreviations}

DCDC2: Doublecortin domain-containing 2; HCC: Hepatocellular carcinoma; SNP: Single nucleotide polymorphism; RT-PCR: Reverse transcription-polymerase chain reaction; MSP: Methylation specific polymerase chain reaction; $\mathrm{LOH}$ : Loss of heterozygosity; HT: HCC tissue; NT: Normal tissue; 5-aza-dC: 5-Aza-2'deoxycytidine; SFRP1: Secreted frizzled-related protein 1; MDS: Myelodysplastic syndrome.

\section{Competing interests}

The authors declare that they have no competing interests.

\section{Authors' contributions}

YI: Analyzing data, experimental work, and drafting article. SN: Conception, design, experimental work, and acquiring data from array analysis. $\mathrm{MH}$ : Experimental work. MH: Analyzing data and experimental work. MK: Experimental work. YN: Experimental work. ST: Sample collection. HS: Sample collection. TF: Sample collection SY: Sample collection. YK: Sample collection. All authors read and approved the final manuscript.

\section{Acknowledgements}

This work was supported by Japan Society for the Promotion of Science (JSPS) KAKENHI Grant-in-Aid for Scientific Research (C) Number 22591427.

Received: 13 July 2013 Accepted: 9 September 2013

Published: 14 September 2013 
References

1. Lau WY, Lai EC: Hepatocellular carcinoma: current management and recent advances. Hepatobiliary Pancreat Dis Int 2008, 7:237-257.

2. Llovet JM, Burroughs A, Bruix J: Hepatocellular carcinoma. Lancet 2003, 362:1907-1917.

3. Livraghi T, Goldberg SN, Lazzaroni S, Meloni F, Solbiati L, Gazelle GS: Small hepatocellular carcinoma: treatment with radio-frequency ablation versus ethanol injection. Radiology 1999, 210:655-661.

4. Takayasu K, Arii S, Ikai I, Omata M, Okita K, Ichida T, Matsuyama Y, Nakanuma Y, Kojiro M, Makuuchi M, Yamaoka Y: Prospective cohort study of transarterial chemoembolization for unresectable hepatocellular carcinoma in 8510 patients. Gastroenterology 2006, 131:461-469.

5. Abou-Alfa GK, Schwartz L, Ricci S, Amadori D, Santoro A, Figer A, De Greve J, Douillard JY, Lathia C, Schwartz B, Taylor I, Moscovici M, Saltz LB: Phase II study of sorafenib in patients with advanced hepatocellular carcinoma. J Clin Oncol 2006, 24:4293-4300.

6. Yu MC, Yuan JM: Environmental factors and risk for hepatocellular carcinoma. Gastroenterology 2004, 127:72-78.

7. Cusnir M, Patt YZ: Novel systemic therapy options for hepatocellular carcinoma. Cancer J 2004, 10:97-103.

8. El-Serag HB, Rudolph KL: Hepatocellular carcinoma: epidemiology and molecular carcinogenesis. Gastroenterology 2007, 132:2557-2576.

9. Okabe H, Satoh S, Kato T, Kitahara O, Yanagawa R, Yamaoka Y, Tsunoda T, Furukawa $Y$, Nakamura Y: Genome-wide analysis of gene expression in human hepatocellular carcinomas using CDNA microarray: identification of genes involved in viral carcinogenesis and tumor progression. Cancer Res 2001, 61:2129-2137.

10. Wang M, Senger RS, Paredes C, Banik GG, Lin A, Papoutsakis ET: Microarray-based gene expression analysis as a process characterization tool to establish comparability of complex biological products: scale-up of a whole-cell immunotherapy product. Biotechnol Bioeng 2009, 104:76-808.

11. Inagaki Y, Yasui K, Endo M, Nakajima T, Zen K, Tsuji K, Minami M, Tanaka S, Taniwaki M, Itoh Y, Arii S, Okanoue T: CREB3L4, INTS3, And SNAPAP are targets for the 1q21 amplicon frequently detected in hepatocellular carcinoma. Cancer Genet Cytogenet 2008, 180:30-36.

12. Kanda M, Nomoto S, Okamura $\mathrm{Y}$, Nishikawa $\mathrm{Y}$, Sugimoto H, Kanazumi $\mathrm{N}$, Takeda S, Nakao A: Detection of metallothionein $1 \mathrm{G}$ as a methylated tumor suppressor gene in human hepatocellular carcinoma using a novel method of double combination array analysis. Int J Oncol 2009, 35:477-483.

13. Nomoto S, Kanda M, Okamura Y, Nishikawa Y, Qiyong L, Fujii T, Sugimoto H, Takeda S, Nakao A: Epidermal growth factor-containing fibulin-like extracellular matrix protein 1, EFEMP1, a novel tumor-suppressor gene detected in hepatocellular carcinoma using double combination array analysis. Ann Surg Oncol 2010, 17:923-932.

14. Okamura Y, Nomoto S, Kanda M, Li Q, Nishikawa Y, Sugimoto H, Kanazumi N, Takeda S, Nakao A: Leukemia inhibitory factor receptor (LIFR) is detected as a novel suppressor gene of hepatocellular carcinoma using double-combination array. Cancer Lett 2010, 289:170-177.

15. Okamura Y, Nomoto S, Kanda M, Hayashi M, Nishikawa Y, Fujii T, Sugimoto $\mathrm{H}$, Takeda S, Nakao A: Reduced expression of reelin (RELN) gene is associated with high recurrence rate of hepatocellular carcinoma. Ann Surg Oncol 2011, 18:572-579.

16. Kanda M, Nomoto S, Okamura Y, Hayashi M, Hishida M, Fujii T, Nishikawa Y Sugimoto H, Takeda S, Nakao A: Promoter hypermethylation of fibulin 1 gene is associated with tumor progression in hepatocellular carcinoma. Mol Carcinog 2011, 50:571-579.

17. Hayashi M, Nomoto S, Kanda M, Okamura Y, Nishikawa Y, Yamada S, Fujii T, Sugimoto $H$, Takeda S, Kodera Y: Identification of the A kinase anchor protein 12 (AKAP12) gene as a candidate tumor suppressor of hepatocellular carcinoma. J Surg Oncol 2012, 105:381-386.

18. Okamura $Y$, Nomoto S, Hayashi M, Hishida M, Nishikawa Y, Yamada S, Fujii T, Sugimoto H, Takeda S, Kodera Y, Nakao A: Identification of the bleomycin hydrolase gene as a methylated tumor suppressor gene in hepatocellular carcinoma using a novel triple-combination array method. Cancer Lett 2011, 312:150-157.

19. Reiner O, Coquelle FM, Peter B, Levy T, Kaplan A, Sapir T, Orr I, Barkai N, Eichele G, Bergmann S: The evolving doublecortin (DCX) superfamily. BMC Genomics 2006, 7:188.
20. Gleeson JG, Lin PT, Flanagan LA, Walsh CA: Doublecortin is a microtubule-associated protein and is expressed widely by migrating neurons. Neuron 1999, 23:257-271.

21. Meng H, Smith SD, Hager K, Held M, Liu J, Olson RK, Pennington BF, DeFries JC, Gelernter J, O'Reilly-Pol T, Somlo S, Skudlarski P, Shaywitz SE, Shaywitz BA, Marchione K, Wang Y, Paramasivam M, LoTurco JJ, Page GP, Gruen JR: DCDC2 Is associated with reading disability and modulates neuronal development in the brain. Proc Natl Acad Sci USA 2005, 102:17053-17058

22. Schumacher J, Anthoni H, Dahdouh F, König IR, Hillmer AM, Kluck N, Manthey M, Plume E, Warnke A, Remschmidt H, Hülsmann J, Cichon S, Lindgren CM, Propping P, Zucchelli M, Ziegler A, Peyrard-Janvid M, SchulteKörne G, Nöthen MM, Kere J: Strong genetic evidence of DCDC2 as a susceptibility gene for dyslexia. Am J Hum Genet 2006, 78:52-62.

23. Paracchini S, Scerri T, Monaco AP: The genetic lexicon of dyslexia. Annu Rev Genomics Hum Genet 2007, 8:57-79.

24. McGrath LM, Smith SD, Pennington BF: Breakthroughs in the search for dyslexia candidate genes. Trends Mol Med 2006, 12:333-341.

25. Longoni N, Kunderfranco P, Pellini S, Albino D, Mello-Grand M, Pinton S, D'Ambrosio G, Sarti M, Sessa F, Chiorino G, Catapano CV, Carbone GM: Aberrant expression of the neuronal-specific protein DCDC2 promotes malignant phenotypes and is associated with prostate cancer progression. Oncogene 2013, 32:2315-2324.

26. Bibikova M, Fan JB: GoldenGate assay for DNA methylation profiling. Methods Mol Biol 2009, 507:149-163.

27. Takai $\mathrm{D}$, Jones PA: The $\mathrm{CpG}$ island searcher: a new WWW resource. In Silico Biol 2003, 3:235-240.

28. Jones PA, Baylin SB: The fundamental role of epigenetic events in cancer. Nat Rev Genet 2002, 3:415-428.

29. Jones PA, Laird PW: Cancer epigenetics comes of age. Nat Genet 1999, 21:163-167.

30. Herman JG, Baylin SB: Gene silencing in cancer in association with promoter hypermethylation. N Engl J Med 2003, 349:2042-2054.

31. Yoshikawa H, Matsubara K, Qian GS, Jackson P, Groopman JD, Manning JE, Harris CC, Herman JG: SOCS-1, a negative regulator of the JAK/STAT pathway, is silenced by methylation in human hepatocellular carcinoma and shows growth-suppression activity. Nat Genet 2001, 28:29-35.

32. Wong IH, Lo YM, Zhang J, Liew CT, Ng MH, Wong N, Lai PB, Lau WY, Hjelm NM, Johnson PJ: Detection of aberrant p16 methylation in the plasma and serum of liver cancer patients. Cancer Res 1999, 59:71-73.

33. Yang B, Guo M, Herman JG, Clark DP: Aberrant promoter methylation profiles of tumor suppressor genes in hepatocellular carcinoma. Am J Pathol 2003, 163:1101-1107.

34. Lee S, Lee HJ, Kim JH, Lee HS, Jang JJ, Kang GH: Aberrant CpG island hypermethylation along multistep hepatocarcinogenesis. Am J Pathol 2003, 163:1371-1378.

35. Massinen S, Hokkanen ME, Matsson H, Tammimies K, Tapia-Páez I, Dahlström-Heuser V, Kuja-Panula J, Burghoorn J, Jeppsson KE, Swoboda P, Peyrard-Janvid M, Toftgård R, Castrén E, Kere J: Increased expression of the dyslexia candidate gene DCDC2 affects length and signaling of primary cilia in neurons. PLoS One 2011, 6:e20580.

36. Giles RH, van Es $\mathrm{JH}$, Clevers H: Caught up in a Wnt storm: Wnt signaling in cancer. Biochim Biophys Acta 2003, 1653:1-24.

37. Wong CM, Fan ST, Ng IO: Beta-catenin mutation and overexpression in hepatocellular carcinoma: clinicopathologic and prognostic significance. Cancer 2001, 92:136-145.

38. Shih YL, Shyu RY, Hsieh CB, Lai HC, Liu KY, Chu TY, Lin YW: Promoter methylation of the secreted frizzled-related protein 1 gene SFRP1 is frequent in hepatocellular carcinoma. Cancer 2006, 107:579-590.

39. Nomoto S, Kinoshita T, Kato K, Otani S, Kasuya H, Takeda S, Kanazumi N, Sugimoto $\mathrm{H}$, Nakao A: Hypermethylation of multiple genes as clonal markers in multicentric hepatocellular carcinoma. Br J Cancer 2007, 97:1260-1265

40. Shih YL, Hsieh CB, Lai HC, Yan MD, Hsieh TY, Chao YC, Lin YW: SFRP1 Suppressed hepatoma cells growth through Wnt canonical signaling pathway. Int J Cancer 2007, 121:1028-1035.

41. Kaur P, Mani S, Cros MP, Scoazec JY, Chemin I, Hainaut P, Herceg Z: Epigenetic silencing of sFRP1 activates the canonical Wnt pathway and contributes to increased cell growth and proliferation in hepatocellular carcinoma. Tumour Biol 2012, 33:325-336. 
42. Gallinari P, Di Marco S, Jones P, Pallaoro M, Steinkühler C: HDACs, histone deacetylation and gene transcription: from molecular biology to cancer therapeutics. Cell Res 2007, 17:195-211.

43. Su Z, Xia J, Zhao Z: Functional complementation between transcriptional methylation regulation and post-transcriptional microRNA regulation in the human genome. BMC Genomics 2011, 12(5):S15.

44. Kantarjian H, Issa JP, Rosenfeld CS, Bennett JM, Albitar M, DiPersio J, Klimek V, Slack J, de Castro C, Ravandi F, Helmer R 3rd, Shen L, Nimer SD, Leavitt R, Raza A, Saba H: Decitabine improves patient outcomes in myelodysplastic syndromes: results of a phase III randomized study. Cancer 2006, 106:1794-1803.

45. Daskalakis M, Nguyen TT, Nguyen C, Guldberg P, Köhler G, Wijermans P, Jones PA, Lübbert M: Demethylation of a hypermethylated P15/INK4B gene in patients with myelodysplastic syndrome by 5-Aza-2'-deoxycytidine (decitabine) treatment. Blood 2002, 100:2957-2964.

doi:10.1186/1756-9966-32-65

Cite this article as: Inokawa et al.: Detection of doublecortin domaincontaining 2 ( $D C D C 2)$, a new candidate tumor suppressor gene of

hepatocellular carcinoma, by triple combination array analysis. Journal of Experimental \& Clinical Cancer Research 2013 32:65.

\section{Submit your next manuscript to BioMed Central and take full advantage of:}

- Convenient online submission

- Thorough peer review

- No space constraints or color figure charges

- Immediate publication on acceptance

- Inclusion in PubMed, CAS, Scopus and Google Scholar

- Research which is freely available for redistribution 